\title{
MAIS EDUCAÇÃO! MAIS SOLIDARIEDADE! MAIS CIÊNCIA!
}

Apesar de a ficção ter antecipado inúmeras vezes e de a ciência ter alertado outras tantas quanto às possibilidades de a humanidade passar por evento(s) pandêmico(s), isso parecia algo distante que remontava a fatos históricos e, mais uma vez, a algo do plano ficcional ou alarmismo de cientistas pouco conectados à realidade. 0 mundo, até então, parecia imune a esse tipo de acontecimento. Talvez a incredulidade de gestores e da multidão em geral se devesse às inúmeras crises que teimam em assolar a humanidade: guerras, fome, instabilidades políticas, volatilidades das bolsas de valores, desavenças étnico-religiosas e muito mais, que demandavam uma atenção imediata.

Inesperadamente, em dezembro de 2019, a sociedade global foi alertada sobre a existência de um vírus em uma província distante e desconhecida localizada no território chinês de Wuhan. Mas mesmo esse alerta não foi suficiente para mobilizar governos e boa parte da comunidade científica internacional. Entretanto, um mês depois, em janeiro de 2020, devido à gravidade dos casos e à rapidez com que o vírus se propagava, a Organização Mundial da Saúde (OMS) já classificava a situação na China de Emergência de Saúde Pública de Âmbito Internacional. E, em 11 de março do mesmo ano, os acontecimentos de saúde envolvendo o desconhecido vírus da Covid-19 entraram na categoria de pandemia. Desde então, a vida de todos nós virou de ponta-cabeça!

Em todo o mundo, milhões de pessoas foram infectadas e outras milhões de mortes contabilizadas até o momento. No Brasil, já se chegou ao fatídico número de meio milhão de óbitos. Infelizmente, os números só crescem e há o reconhecimento das autoridades sanitárias quanto à provável subnotificação, ou seja, o cenário é bem mais grave do que o retratado pelas estatísticas oficiais. Os efeitos dramáticos da pandemia não se restringem ao campo tradicional da saúde. Observam-se rebatimentos na economia, na educação, na política, na demografia, nas sociabilidades, entre outros. Destaca-se o fato de que os mais vulneráveis são as principais vítimas dessa situação sanitária. Em todo o globo são os pobres e as populações marginalizadas que estatisticamente se tornam as vítimas mais suscetíveis de contraírem e evoluírem gravemente em relação à Covid-19.

Há consensos entre as principais agências de saúde do mundo e também entre renomados pesquisadores sobre medidas preventivas que ajudam na contenção da propagação da pandemia. Essas providências passam pela prática do distanciamento social, o uso de máscaras e a higiene de ambientes e, principalmente, das mãos, por meio do uso de água e sabão ou do álcool em gel, de modo sistemático, além de políticas de assistência social para as populações mais vulneráveis a fim de mitigar os efeitos da pandemia. Finalmente, o desenvolvimento de vacinas e sua aplicação em massa, globalmente, como estratégia para uma gestão eficiente da crise sanitária. Simples, deveria ser, mas a comunidade de humanos é bem mais complexa do que se tende a supor.

0 dramático de toda essa situação tem sido a proliferação de ideias polêmicas que negam as orientações de base científica. Do dia para a noite, assiste-se de forma atônita que qualquer leigo, sem uma formação minimamente adequada, instruído via de regra no subuniverso das redes sociais, passa a propagar informações que vão na contramão da boa ciência. Agrega-se o fato de gestores públicos ocupantes de cargos em diferentes níveis endossarem tais ideias e adotarem comportamentos negacionistas. Trata-se de uma minoria, é verdade, porém suas posturas trazem enormes prejuízos à boa gestão da pandemia. Informações falsas e lideranças não comprometidas com os preceitos científicos confundem e induzem pessoas a comportamentos não compatíveis com os cuidados necessários nestes tempos de pandemia. 
A crise sanitária passou a ser, também, uma crise política e de valores. 0 obscurantismo, que se pensava superado desde os tempos do Iluminismo e, mais recentemente, pelas importantes conquistas que a ciência vinha agregando ao desenvolvimento humano, ressurge com muita vitalidade. Tempos estranhos onde a falta de empatia e a política da morte desafiam governos e cidadãos que tentam orientar suas práticas com base em pressupostos científicos e éticos.

Um dos desfechos do cenário descrito é o agravamento da crise sanitária, que tem sua resolução adiada. Outro desdobramento está no aumento do sofrimento da população, que, além das mortes dos entes queridos e das sequelas que podem advir de quem contraiu a Covid-19, vê aumentados o estresse, o adoecimento mental e os impactos socioeconômicos como o empobrecimento, a perda do emprego, entre outros. 0s profissionais da saúde que atuam na linha de frente sofrem cada vez mais da fadiga de compaixão dado o prolongado processo de enfrentamento da pandemia.

Malgrado todos esses percalços aqui relatados, verifica-se que a ciência, mesmo sofrendo uma virulenta tentativa de desqualificação, foi capaz de, em tempo recorde, produzir respostas altamente positivas que se traduziram em novos e importantes conhecimentos nos campos da microbiologia, da epidemiologia, da imunologia (no caso das vacinas) e dos cuidados em saúde. A sociedade em geral tem apoiado e acolhido as orientações da comunidade científica. Gestos de solidariedade são registrados em todos os lugares. 0s profissionais da saúde, apesar do cansaço extremo, não recuaram na sua missão de salvar vidas. Cada vida importa. Resistir ao negacionismo e à falta de empatia representa um compromisso com a ciência e com a vida. Vai dar certo!!!!

Finalmente, é fundamental o movimento de sistematização dos muitos dos achados e aprendizados que todo esse complexo processo da pandemia tem proporcionado a duras penas. A divulgação dos inúmeros trabalhos de pesquisa em todo o globo é determinante para difundir conhecimentos e dar credibilidade às recomendações dos profissionais de saúde. Este deve ser um movimento constante - estimular a leitura de evidências científicas e dar visibilidade aos resultados de pesquisa que influenciam a realidade da sociedade.

Fica, então, o convite para a leitura do v.20, n.1, 2021, da SANARE - Revista de Políticas Públicas e, assim, a análise acerca das interpretações advindas e reflexão sobre como melhor conduzir práticas em saúde, pois não se faz boa ciência sem transparência e compartilhamentos.

Boa leitura!

\author{
José Reginaldo Feijão Parente \\ Psicólogo \\ Universidade Estadual Vale do Acaraú - UVA \\ Doutor em Educação e em Psicologia \\ https://orcid.org/0000-0002-6739-0985 \\ E-mail: reginaldo.fp@hotmail.com
}

